Jurnal Indonesia Sosial Teknologi: p-ISSN: 2723 - 6609

e-ISSN : 2745-5254

Vol. 2, No. 4 April 2021

\title{
PENDEKATAN ARSITEKTUR MODERN MINIMALIS PADA BANGUNAN PERKANTORAN
}

\author{
Ahmad Siena Farizi dan Wafirul Aqli \\ Program Studi Arsitektur, Universitas Muhammadiyah Jakarta \\ Email:2016460004@ftumj.ac.id,wafirul.aqli@ftumj.ac.id
}

\begin{abstract}
Modern minimalist architecture is an architectural theme that pays attention to prioritizing functionality and efficiency without neglecting the aesthetic aspects of the building. This architectural theme is a blend of modern and minimalist architecture. Modern minimalist architecture is a suitable theme when applied in office buildings. With the existence of modern minimalist architecture, there are still office buildings that are unable to meet the needs of office activities due to lack of understanding of the application of the principles of modern minimalist architecture. Therefore, this study aims to provide direction and encourage the application of office space design based on modern minimalist architecture in accordance with applicable principles. This research was conducted using a qualitative descriptive method so that the data obtained is more in-depth and detailed. Each principle will be discussed in accordance with the condition of the building which is used as a study, discussing the compatibility of modern minimalist principles with the actual situation which contains advantages and disadvantages. The conclusion put forward in this study is to show the modern minimalist principle approach in office buildings and also its application in office buildings.
\end{abstract}

Keyword: architecture; modern minimalist; modern; minimalist

\begin{abstract}
Abstrak
Arsitektur modern minimalis merupakan tema arsitektur memperhatikan mengutamakan fungsionalitas dan efesiensi tanpa mengenyampingkan aspek estetika bangunan. Tema arsitektur ini merupakan perpaduan antara arsitektur modern dengan minimalis. Arsitektur modern minimalis merupakan tema yang cocok jika diterapkan di bangunan perkantoran. Dengan adanya Arsitektur modern minimalis tetap masih ada bangunan perkantoran yang tidak mampu memenuhi kebutuhan aktifitas perkantoran dikarenakan masih kurang pahamnya penerapan prinsip-prinsip dari arsitektur modern minimalis. Oleh karena itu penelitian ini bertujuan untuk memberikan arahan dan mendorong penerapan desain ruang kantor yang berlandaskan arsitektur modern minimalis sesuai dengan prinsip-prinsip yang berlaku. Penelitian ini dikerjakan menggunakan metode deskriptif kualitatif agar data yang didapatkan lebih dalam dan detail. Tiap prinsip akan dibahas sesuai dengan keadaan bangunan yang dijadikan sebagi studi, membahas kompatibilitas prinsip modern minimalis dengan keadaan yang sebenarnya yang memuat keunggulan dan kekurangannya. Kesimpulan yang dikemukakan dalam penelitian ini adalah
\end{abstract}


menunjukan pendekatan prinsip modern minimalis pada bangunan perkantoran dan juga penerapannya pada gedung perkantoran.

Kata kunci: arsitektur; modern minimalis; modern; minimalis

\section{Pendahuluan}

Menurut (Sedarmayanti, 2017) jumlah penduduk mengalami kenaikan setiap tahunnya. Kenaikan ini dipengaruhi oleh banyak faktor seperti urbanisasi, meningkatnya fertilisasi, dan menurunnya angka kematian. Akibatnya angka persaingan makin tinggi, banyak individu yang lebih memilih untuk mendirikan usaha pribadi atau sebuah perusahaan swasta (Sulastri, 2016). Dengan banyaknya jumlah perusahaan swasta yang berdiri, persaingan akan tetap terjadi, perusahaan dituntut untuk memiliki kinerja yang unggul agar dapat tetap memimpin diantara perusahaan lainnya (Abdullah, 2014). Perusahaan yang unggul memiliki management yang baik, mulai dari pemasaran, pengaturan sumber daya, produksi, keuangan dan lain-lain (Rozarie \& Indonesia, 2017). Semua hal tersebut diatur dalam sebuah office yang dioperasikan oleh karyawankaryawan. Oleh karena itu karyawan merupakan hal yang vital sehingga karyawan dituntut untuk bekerja semaksimal dan seefektif mungkin, produktivitas merupakan kunci kesuksesan dalam sebuah perusahaan (Nuraida, 2018).

Namun banyak desain kantor yang kurang sesuai dan gagal dalam memenuhi kebutuhan karyawan terutama desain ruang perkantoran yang mengakibatkan minimnya produktivitas dan performa penggunanya (Walidonna, 2017). Untuk mengatasi permasalahan ini, kebutuhan karyawan-karyawan kantor harus dapat dipenuhi dalam melakukan aktivitas yang relevan pada ruang tersebut. Oleh karena itu dibutuhkan desain yang sesuai untuk memenuhi kebutuhan karyawa-karyawan salah satunya desain ruang kantor modern minimalis. Mengapa? Karena desain ruang kantor modern minimalis mengutamakan fungsionalitas, mengutamakan fungsi dan kebutuhan dibanding estetika. Arsitektur Modern Minimalis merupakan perencanaan yang memiliki estetika yang di dominasi oleh perpaduan unsur horizontal dengan vertikal, ruang hampa dengan masif, simetri dengan asimetri, geometris abstrak dengan bentuk melengkung, statik dengan dinamik yang dimana semua unsur ini memiliki sebuah batasan yang jelas namun tetap harmonis dan saling melengkapi. Sehingga konsep modern minimalis merupakan konsep yang tidak sepenuhnya meninggalkan aspek estetika yang memanfaatkan perbedaan elemen dengan rasio yang harmonis (Wahjutami, 2017).

Arsitektur modern minimalis juga memiliki prinsip penghematan dalam penggunaan segi ruang yang berdasarkan studi kebutuhan ruang yang didasari penataan dan pembentukan ruang. Konsep modern minimalis memaksimalkan penggunaan sumber cahaya alami dengan bukaan yang cukup luas. Konsep ini juga menerapkan penghematan penggunaan massa terhadap ruang yang memiliki luas berlebih dengan meminimalisir massa bangunan \& desain yang padat. Arsitektur modern minimalis memaksimalkan karakteristik asli bangunan dengan menjelajahi struktur dan material yang digunakan yang dijadikan sebagai aspek estetika bangunan, salah satunya dengan permainan bentuk 
geometri yang sederhana yang diperkuat oleh pembentukan garis-garis bangunan horizontal dan vertikal. Penggunaan perabot yang minim juga menghasilkan ruang yang lebih rapi dan tertata, memberikan kesan ruang lebih lapang, bersih dan juga lebih profesional membuat penggunanya lebih rileks, nyaman, dan efisien (Wicaksono \& Tisnawati, 2014). Dengan menerapkan konsep-konsep yang di tawarkan oleh konsep modern minimalis akan menghasilkan lebih banyak ruang untuk berinteraksi lebih lua dan meningkatkan komunikasi yang berdampak positif pada produktivitas karyawan dan masih banyak lagi keunggulan desain modern minimalis (Lukito \& Handoko, 2018). Berdasarkan manfaat dan keunggulan diatas, desain ruang kantor yang bertemakan modern minimalis merupakan pendekatan yang patut untuk diteliti dampaknya yang dapat berdampak dalam meningkatkan produktivitas di ruang perkantoran.

\section{Metode Penelitian}

Penelitian ini merupakan jenis penelitian deskriptif kualitatif, yang bertujuan untuk memperdalam atau memperjelas detail mengenai sebuah kasus yang diajukan oleh peneliti. Penelitian ini memiliki hubungan dengan ide, persepsi atau pendapat dengan kasus yang diteliti. Penelitian ini disusun untuk menyampaikan keadaan suatu kasus yang bersifat nyata yang terjadi di lokasi survey melalui hipotesis dan interaksi langsung (Prasanti, 2018).

Berikut adalah langkah-langkah penelitian yang dilakukan:

1. Persiapan (Tahap pra-lapangan)

Menentukan prioritas penelitian dan mengumpulkan landasan data berdasarkan topik penelitian yang akan dibahas.

2. Eksplorasi \& Observasi

Mencari dan menentukan lokasi lapangan yang relevan dan sesuai dengan pembahasan penelitian. Kemudian mengumpulkan data-data berupa teori, literatur, dan jurnal yang dapat mendukung dan menjadi landasan teori yang sesuai topik penelitian.

3. Analisis Data

Tahap ini merupakan tahap peneliti melakukan analisis dengan memanfaatkan data awal yang didapatkan dari berbagai sumber kemudian dilakukan perbandingan dan dikombinasikan dengan data hasil observasi untuk mendapatkan hasil yang sesuai.

4. Evaluasi

Tahap ini merupakan tahap untuk melakukan pengujian kembali hasil dari penelitian yang telah dilakukan agar hasil yang didapatkan lebih baik dan dapat dipertanggung jawabkan.

5. Finalisasi \& Menarik Kesimpulan.

Pada tahap ini hasil dari semua data yang dianalisis digabungkan dan kemudian ditarik kesimpulan teori yang menghasilkan prinsip-prinsip arsitektur. 


\section{Hasil dan Pembahasan}

Analisis dan pembahasan penelitian pendekatan arsitektur modern pada bangunan perkantoran berfokus pada prinsip-prinsip arsitektur modern minimalis. Pembahasan dari konsep arsitektur modern minimalis disesuaikan dengan kesimpulan teori arsitektur modern minimalis pada bangunan kantor yang berpacu pada prinsip-prinsip arsitek modern minimalis. Untuk mendesain bangunan modern minimalis, elemen reduktif merupakan salah satu faktor penting yang harus diperhatikan. Penggunaan faktor reduktif berfungsi untuk meningkatkan efisiensi dapat ditemukan di berbagai aspek pada kantor Van Spaendonck Enterprise House \& kantor Permata kuningan.

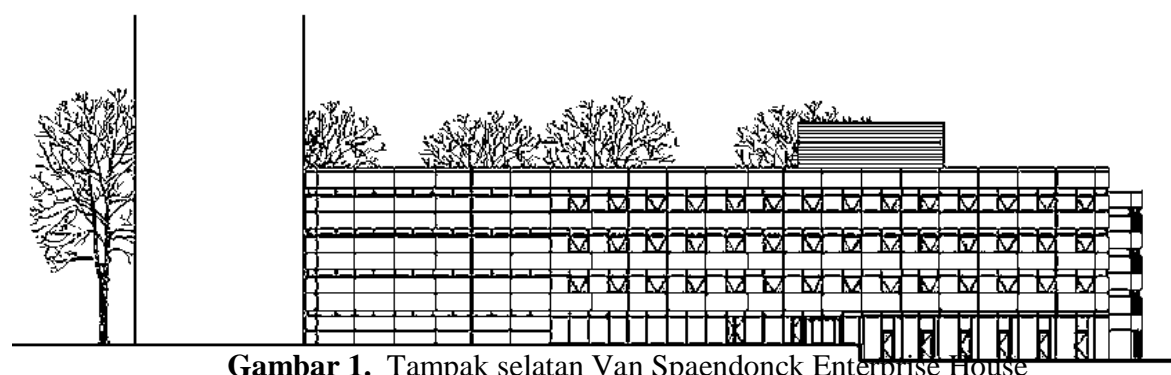

(Sumber: Data Pribadi, 2021).

Pada tampak gambar 1 Van Spaendonck Enterprise House dapat dilihat bahwa tidak terdapat ornamen. Dengan meminimalisir penggunaan ornamen, biaya dan waktu pembangunan bangunan berdiri diminimalisir, begitu juga dengan biaya perawata bangunan. Dengan adanya ornamen akan menambah biaya perawatan dikarenakan meningkatkan beban pekerjaan. Jadi dengan mereduksi penggunaan material dapat meningkatkan efisiensi bangunan. Pemanfaatan elemen reduktif juga dimanfaatkan pada desain kantor Permata Kuningan yang berpotensi meningkatkan efesiensi, mulai dari sirkulasi, waktu pengerjaan,dan biaya pembangunan.

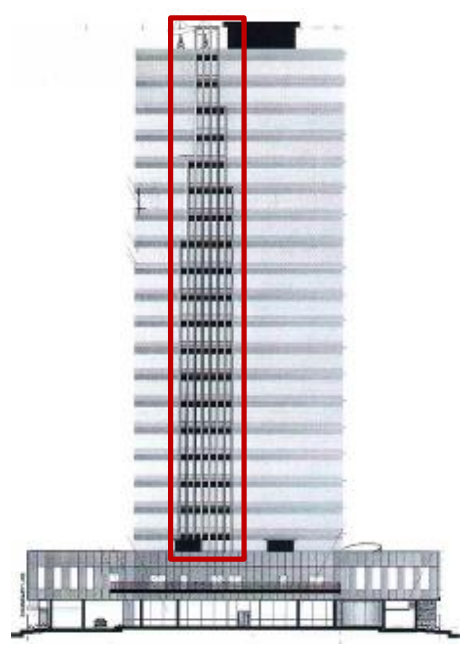

Gambar 2. Ornamen Pada Eksterior Kantor Permata Kuningan (Sumber: Data Pribadi, 2021). 
Pada eksterior Bangunan Kantor Permata Kuningan yang ditampilkan gambar 2 terdapat ornamen precast concrete panels disetiap sisi bangunan. Sebagian besar eksterior bangunan terdiri dari perpaduan dinding kaca dan dinding yang lapisi oleh Aluminium Composite Panel (ACP) pada lantai podium dan lantai tipikal. Dengan melakukan reduksi penggunaan ornamen dapat mengurangi biaya dan kecepatan pengerjaan bangunan, dan menghemat biaya perawatan eksterior bangunan dalam jangka panjangmpak gambar 1 Van Spaendonck Enterprise House dapat dilihat bahwa tidak terdapat ornamen.

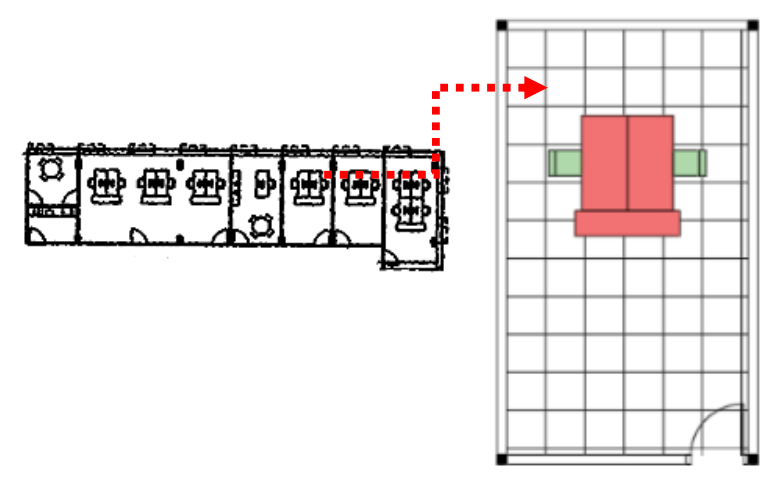

Gambar 3. Detil Interior Van Spaendonck Enterprise House (Sumber: Data Pribadi, 2021).

Terlihat pada gambar 3 pada ruang kantor Van Spaendock Enterprise House, penggunaan perabot juga dikurangi agar memiliki lebar sirkulasi yang lebih luas. Kantor Van Spaendock Enterprise House memiliki beberapa desain ruang kantor yaitu ada ruang yang memiliki tiga meja yang digunakan oleh karyawan, dua meja digunakan untuk karyawan, dan ada ruang yang digunakan untuk penyimpanan arsip, dokumen atau alat perkantoran tambahan. Peralatan perkantoran yang sering digunakan dapat ditempatkan di tiap meja karyawan dan jumlah juga disesuaikan dengan kebutuhan untuk menghindari penggunaan perabot berlebih.
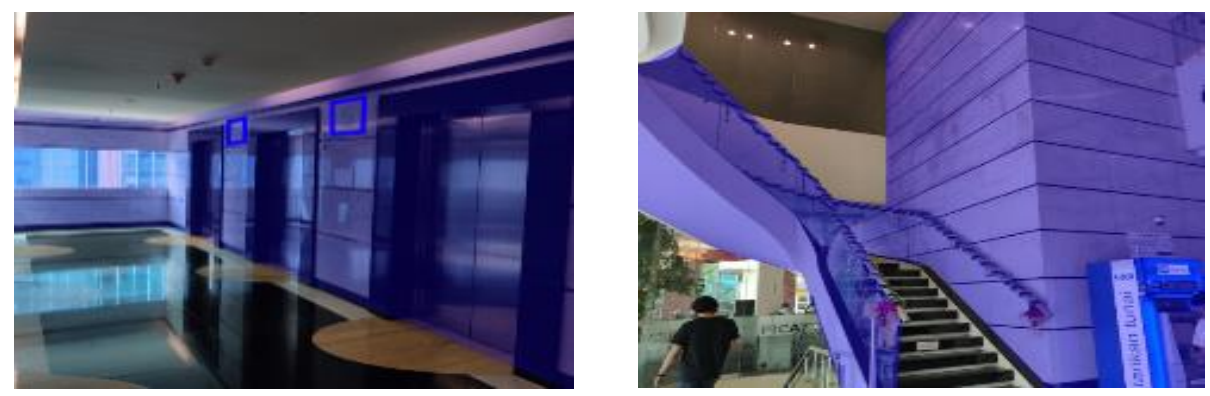

Gambar 4. Ornamen Pada Interior Bangunan Kantor Permata Kuningan (Sumber: Data Pribadi, 2021). 
Elemen reduksi juga diterapkan pada interior Kantor Permata Kuningan yang dilihat dari minimnya penggunaan ornamen. Pada gambar 4 terlihat bagian lobby meminimalisir penggunaan ornamen dikarenakan sumber estetika berasal dari pemanfaatan material dibanding menggunakan ornamen. Minimnya penggunaan ornamen juga dapat dilihat pada selasar lift kantor pada lantai tipikal dimana didominasi oleh penggunaan keramik pada dinding. Dari pereduksian ornamen pada interior bangunan dapat mengurangi biaya perawatan sehingga meningkatkan efesiensi pengeluaran biaya perawatan bangunan.

Tujuan dari penerapan elemen reduksi pada ruang dan tampak kantor ialah menciptakan kenyamanan sirkulasi dengan memberikan ruang lebih pada sirkulasi, tak lupa pengurangan biaya perawatan sehingga sifat berkelanjutan didapatkan oleh bangunan. Dari keunggulan hasil reduksi yang didadapat, efisiensi bangunan menjadi hasil dari elemen reduksi tersebut. Penerapan sifat horizontal dan vertikal pada elemen bangunan kantor kerap dimanfaatkan sebagai estetika pada bangunan memiliki tema dan konsep modern minimalis.

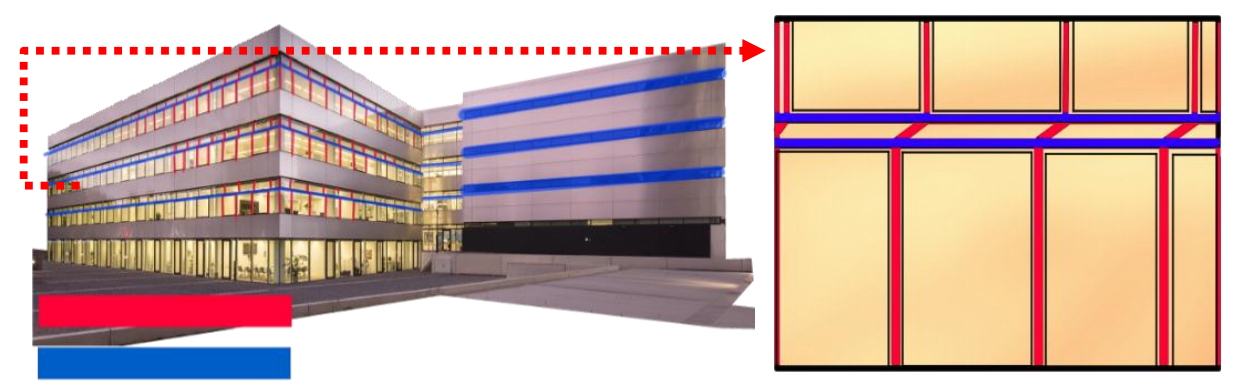

Gambar 5. Elemen horizontal \& vertikal pada fasad Van Spaendonck Enterprise House

(Sumber: Data Pribadi, 2021).

Dapat dilihat pada gambar 5 bahwa pada tampak bangunan Van Spaendonck Enterprise House menggunaan elemen horizontal dan vertikal sebagai elemen pembentuk estetika bangunan. Desain fasad memanfaatkan perbedaan ukuran bukaan yang menghasilkan pola-pola bukaan yang berukuran kecil sehingga terlihat seperti garis horizontal yang membentang pada setiap fasad yang menciptakan suatu ciri khas dari bangunan berkonsep modern minimalis. Pada fasad yang didominasi oleh bukaan jendela, desain bukaan memanfaatkan efek bukaan yang condong kedalam sehingga garis vertical terlihat tidak sejajar meciptakan efek susunan garis vertikal yang tidak sama namun memberikan susunan yang berirama. 


\section{Elemen Vertikal}

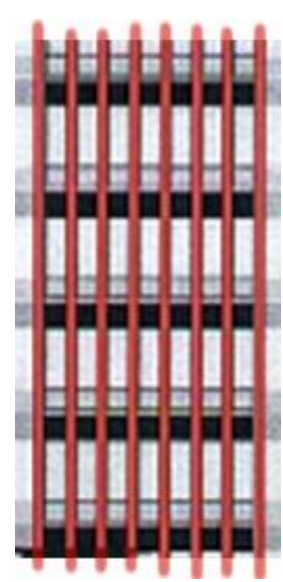

Gambar 6. Elemen Horizontal \& Vertikal Pada Eksterior Bangunan Kantor Permata Kuningan

(Sumber: Data Pribadi, 2021).

Dapat dilihat pada gambar 6 bahwa elemen persimpangan antara garis horizontal dan vertikal dapat ditemukan pada ornamen eksterior Bangunan Kantor Permata Kuningan. Ornamen yang menggunakan elemen garis vertikal ini menjulang hingga bagian tertinggi dari gedung yang didukung oleh persimpangan garis horizontal meningkatkan karakteristik modern pada bangunan. Selain itu elemen vertikal pada ornamen memperkuat kesan bahwa gedung ini merupakan gedung bertingkat tinggi.

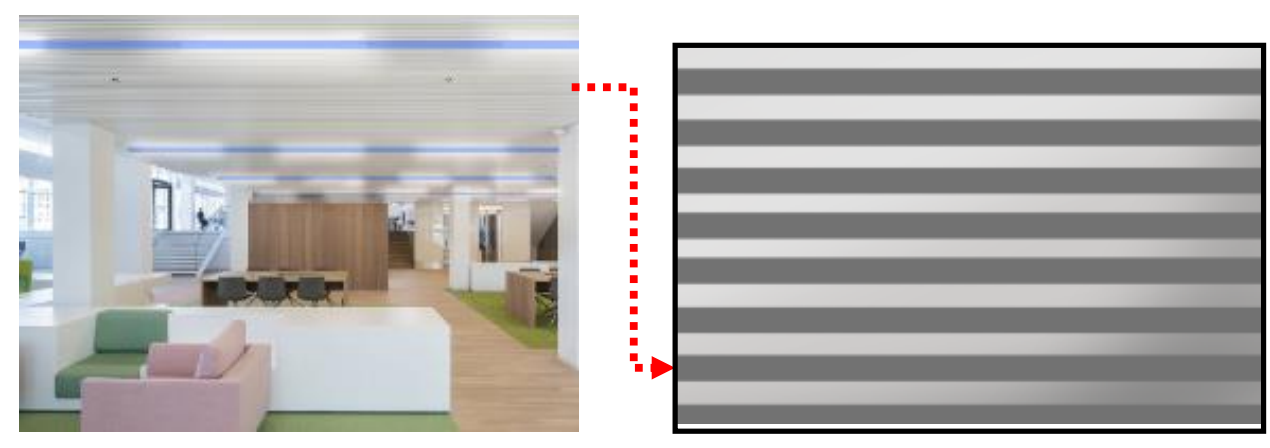

Gambar 7. Elemen Horizontal \& Vertikal Pada Interior Van Spaendonck Enterprise House

(Sumber: Data Pribadi, 2021).

Penggunaan sifat horizontal dan vertikal pada interior juga dapat ditemukan pada plafond tiap ruang yang bersifat privat maupun bersifat publik. Sifat tersebut juga terlihat pada susunan lampu pada langit-langit yang membentuk suatu pola yang bersifat memanjang pada garis dan juga bentuk dari lampu yang berbentuk bulat dan juga persegi panjang. Dengan penerapan sifat tersebut pada langit-langit dan plafond bangunan membuktikan bahwa sifat dari elemen garis horizontal dan vertikal dapat terbentuk hanya dari penataan sederhana. 
Sifat dari elemen garis horizontal dan vertikal dapat diperkuat dengan memanfaatkan tekstur dari plafond itu sendiri, dapat dilihat pada gambar 7 bahwa plafond tersebut terdiri dari susunan garis abu-abu yang lebih gelap pada permukaan plafond yang berwarna abu-abu keperakan. Jika dipadukan dengan susunan lampu, bahwa susunan lampu menjadi elemen garis utama yang paling jelas dan didukung oleh garis-garis abuabu tua yang lebih rapat dan tipis.
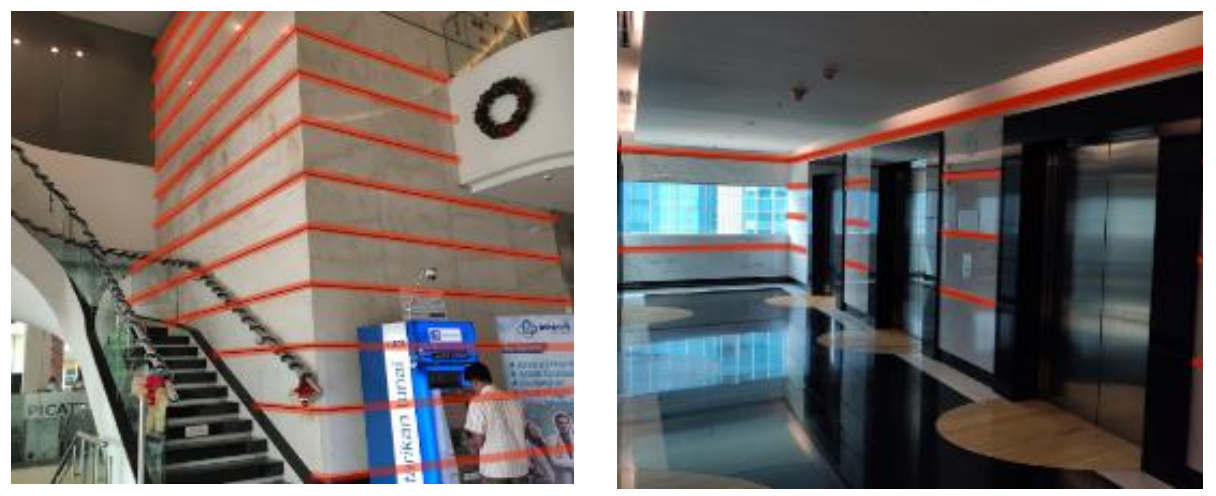

Gambar 8. Elemen Horizontal \& Vertikal Pada Interior Van Spaendonck Enterprise House

(Sumber: Data Pribadi, 2021).

Pada gambar 8 menggambarkan aspek interior Kantor Permata Kuningan, elemen garis horizontal diterapkan pada dinding ruangan. Garis horizontal tersebut memberikan kesan yang megah dan mewah pada lobby dan selasar lift di tiap lantai. Berdasarkan hasil analisis elemen garis horizontal dan vertikal digunakan cukup optimal pada bangunan, elemen ini sukses membentuk karakter gedung tinggi yang megah, mewah dan bergengsi yang cukup menarik minat penyewa.

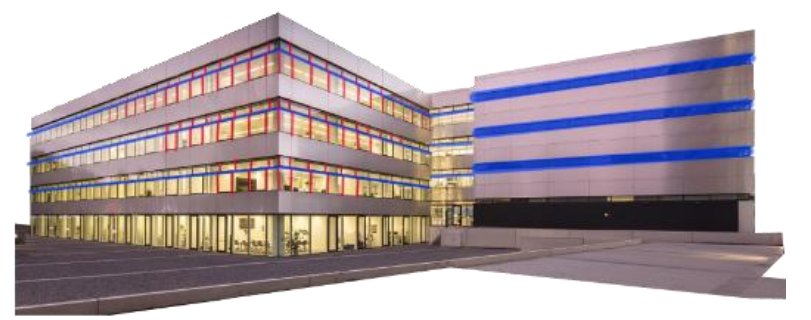

Gambar 9. Netralitas Fasad Van Spaendonck Enterprise House (Sumber: Data Pribadi, 2021). 
Bangunan modern minimalis dianjurkan untuk bersifat netral dan juga menhindari desain-desain yang memiliki arti simbolik untuk mempertahankan sifat dan karakteristik dari modern minimalis itu sendiri. Terlihat pada gambar 9 bahwa fasad bangunan Van Spaendonck Enterprise House didominasi oleh pemanfaatan elemen garis horizontal dan vertikal. Bentuk dari bangunan juga terlihat seperti dua kotak yang terpisah walaupun satu bangunan. Pada fasad bangunan juga terlihat tidak ada suatu ornamen yang memiliki potensi memberikan kesan simbolik atau makna lain. Berdasarkan sifat tersebut terlihat jelas bahwa sifat netral terlihat jelas pada fasad bangunan, begitu juga dengan desain simbolik berdasarkan kesederhanaan bentuk dan tanpa memiliki ornamen.

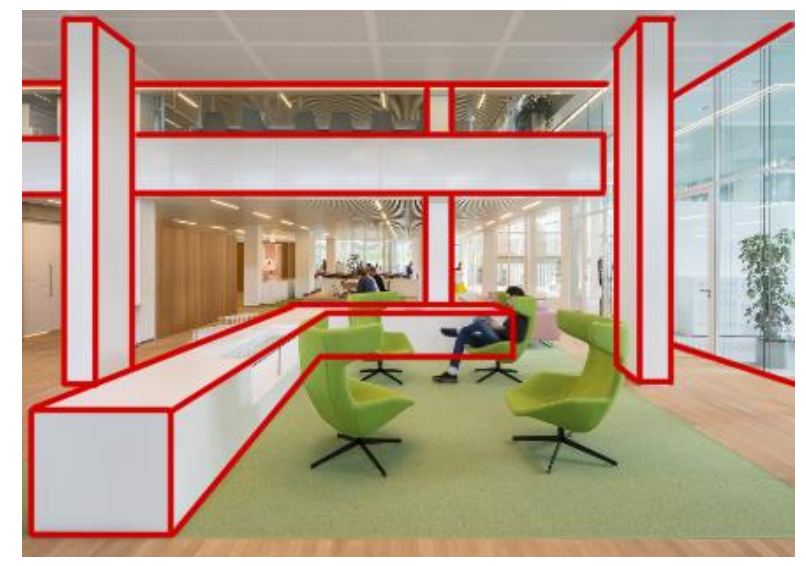

Gambar 10. Netralitas Interior Van Spaendonck Enterprise House (Sumber: Data Pribadi, 2021).

Pada gambar 10 terlihat bahwa desain interior Van Spaendonck Enterprise House terlihat minimnya pemanfaatan ornamen, hanya terdapat dinding kosong yang dilapisi oleh ACP berwarna putih. Bentuk-bentuk dari perabot yang digunakan juga menggunakan bentuk-bentuk sederhana dan tanpa ukiran sama sekali, hanya permukaan yang mulus dan ornamen. Kesan saat melihat ruangan dari Van Spaendonck Enterprise House adalah bahwa ruangan terdapat banyak sekali bentuk-bentuk balok dan persegi yang terbentuk dari kolom, dinding panel dan juga perabot sehingga netralitas dari desain interior terlihat dan juga dapat dirasakan secara jelas.

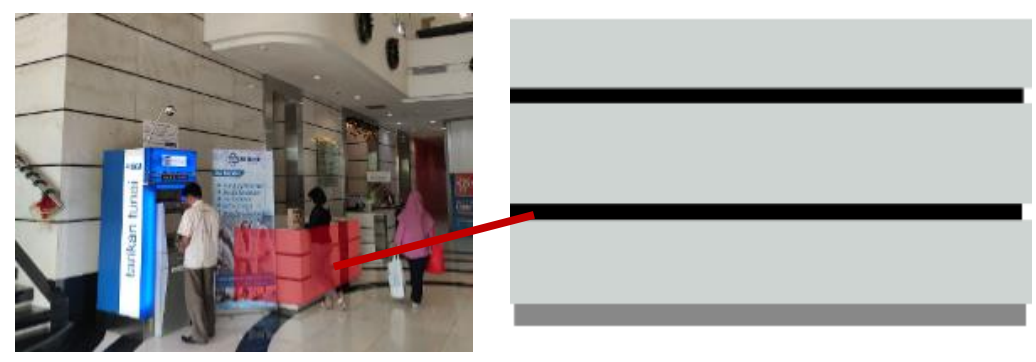

Gambar 11. Netralitas interior Kantor Permata Kuningan (Sumber: Data Pribadi, 2021). 
Dapat dilihat pada gambar 11 bahwa elemen-elemen garis horizontal pada interior Gedung Kantor Permata Kuningan merupakan elemen yang bersifat netral. Elemen ini dapat ditemukan pada dinding lobby, dinding selasar lift, resepsionis dan perabot yang digunakan pada lobby. Desain garis horizontal dan bentuk sederhana juga tidak memberikan arti khusus selain memberi kesan mewah dan megah namun tetap netral layaknya desain yang profesional pada interior kantor.

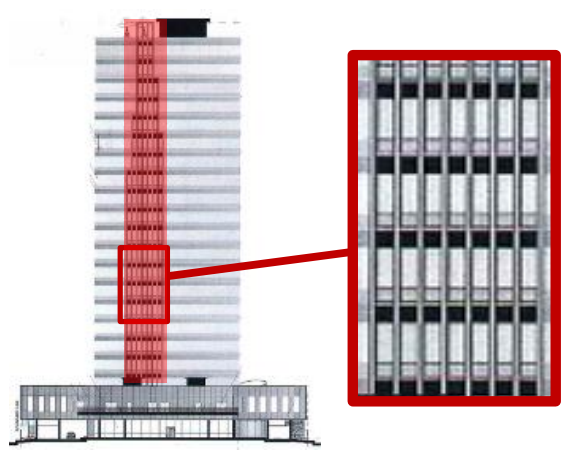

Gambar 12. Netralitas Eksterior Kantor Permata Kuningan (Sumber: Data Pribadi, 2021).

Berdasarkan gambar 12 bahwa ornamen dari kantor Permata Kuningan yang berada di luar bangunan juga memiliki sifat netral yang dikarenakan bentuk ornamen merupakan hasil persimpangan dari elemen garis horizontal dan vertikal, namun ornamen tidak dapat memberikan suatu makna khusus pada ornamen tersebut sehingga netralitas eksterior terjaga.

Pemanfaatan bentuk-bentuk sederhana tanpa memiliki makna tertentu merupakan sumber dari aspek netralitas dan juga dapat membentuk elemen-elemen horizontal dan vertikal sehingga bentuk-bentuk sederhana merupakan prinsip yang cukup penting dalam pembentukan bangunan bersifat modern minimalis.

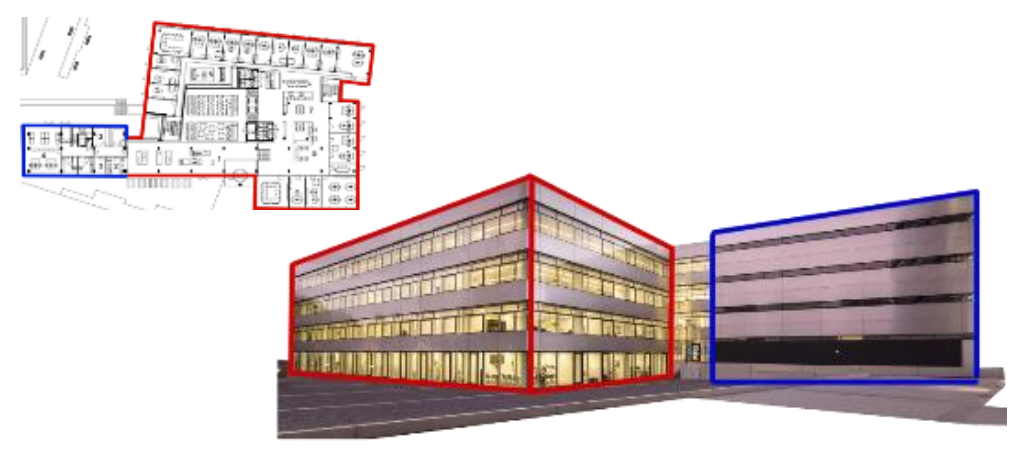

Gambar 13. Bentuk sederhana pada fasad Van Spaendonck Enterprise House (Sumber: Data Pribadi, 2021).

Berdasarkan gambar 13, Van Spaendonck Enterprise House terbentuk dari dua gubahan massa yang berbentuk kotak sehingga kesan pertama yang terbentuk adalah kesederhanaan bentuk dari masifnya Van Spaendonck Enterprise House. Namun jika 
melihat desain denah, Van Spaendonck Enterprise House tidak memiliki bentuk yang sederhana melainkan bentuk yang terlihat sedikit kompleks.

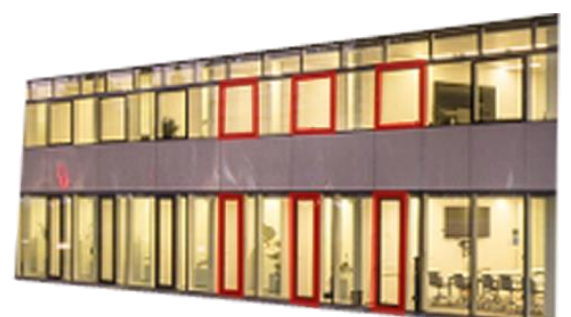

Gambar 14. Bentuk Sederhana Pada Jendela Van Spaendonck Enterprise House (Sumber: Data Pribadi, 2021).

Berdasarkan gambar 14 bahwa bentuk bukaan juga dapat terlihat bentuk-bentuk persegi yang begitu jelas. Pintu yang berbahan utama kaca pada fasad memiliki kusen dan daun pintu hitam yang menciptakan bentuk persegi panjang yang dibagian tengahnya bersifat transparan. Begitu juga dengan bukaan jendelanya.

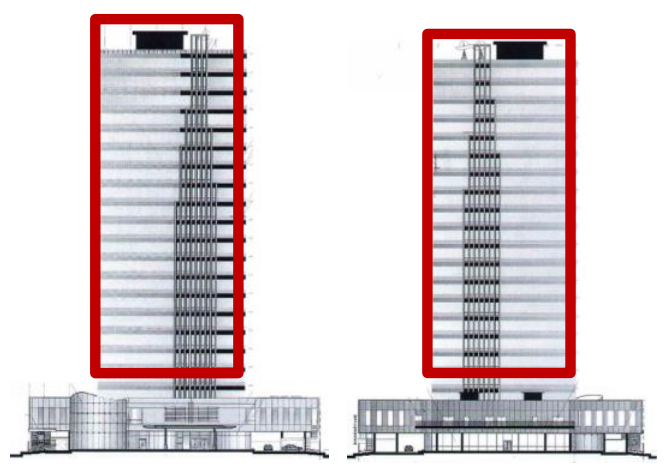

Gambar 15. Bentuk Sederhana Pada Fasad Kantor Permata Kuningan (Sumber: Data Pribadi, 2021).

Dapat dilihat dari gambar 15 bahwa, bangunan permata kuningan memanfaatkan bentuk persegi panjang pada keseluruhan bentuk bangunannya yang menguatkan sifat dari desain modern minimalis. Walaupun bentuk dari bangunan tidak sepenuhnya berbentuk persegi panjang, dengan memanfaatkan sifat gedung tinggi yang masif dapat mengubah persepsi pengamat pada bangunan tersebut.

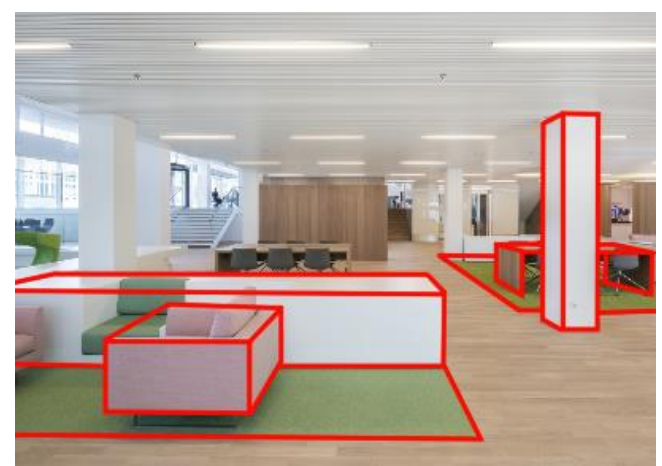

Gambar 16. Bentuk Sederhana Pada Interior Van Spaendonck Enterprise House (Sumber: Data Pribadi, 2021). 
Pada interior Van Spaendonck Enterprise House, bentuk-bentuk sederhana semakin mudah untuk ditemukan. Terlihat pada gambar 16 bahwa terlihat banyak elemen yang membentuk kesan modern minimalis pada ruangan, salah satunya bentuk-bentuk persegi panjang yag dapat ditemukan pada sofa, kursi, karpet, kolom dan lain-lain.

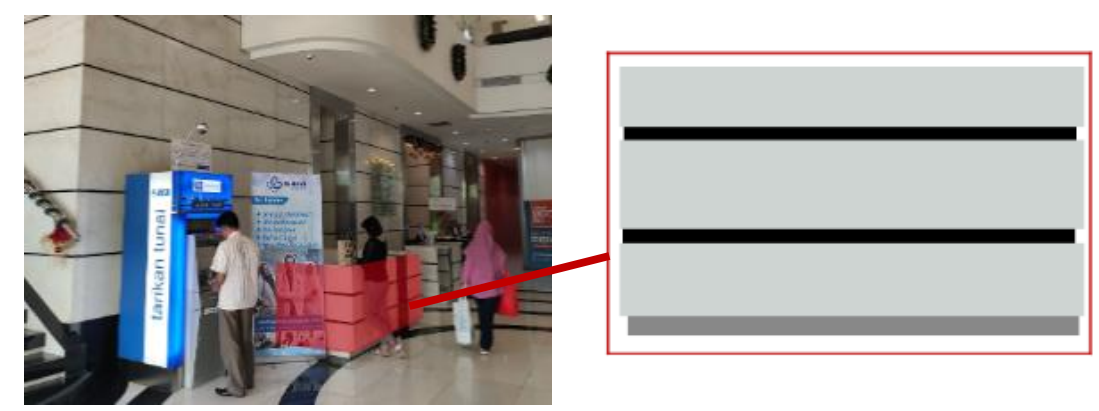

Gambar 17. Bentuk Sederhana Pada Interior Kantor Permata Kuningan (Sumber: Data Pribadi, 2021).

Berdasarkan gambar 17 bahwa bentuk sederhana yang diterapkan oleh interior lobby kantor Permata Kuningan dapat ditemukan pada bentuk meja resepsionis. Bentuk pesergi digunakan untuk menekankan sifat netral pada meja, namun tetap berkelas dengan sedikit sentuhan elemen garis. Dengan menggunakan bentuk-bentuk sederhana terutama pada interior dapat memperkuat kesan profesional pada keseluruhan desain interior bangunan tersebut.

Pemanfaatan material sebagai estetika merupakan hal penting dikarenakan ciri khas dari karakteristik bangunan modern minimalis. Pemanfaatan material sebagai estetika dapat dimanfaatkan pada eksterior maupun interior bangunan. Tujuan umum dari pemanfaatan ini adalah memanfaatkan sifat material yang sudah ada dan digunakan semaksimal mungkin sehingga meminimalisir biaya tambahan seperti finishing dan menambahkan bahan lainnya.

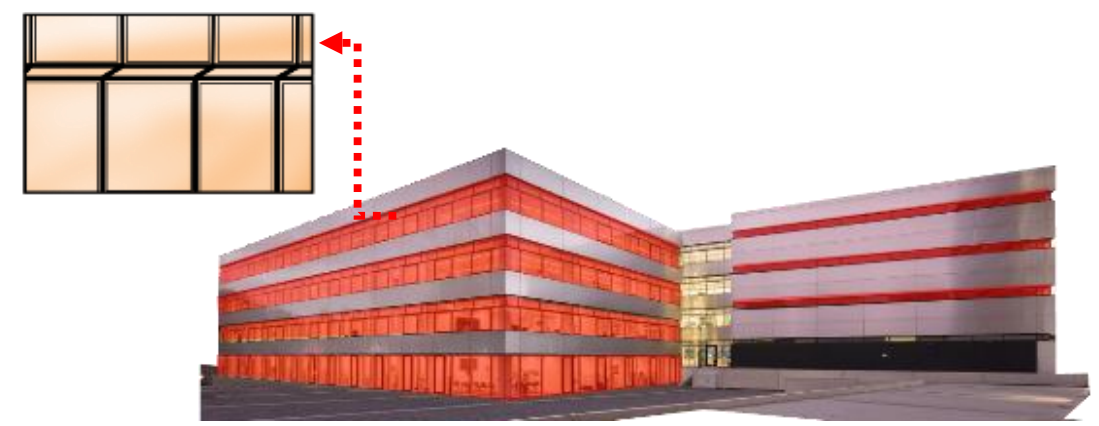

Gambar 18. Pemanfaatan Material Sebagai Estetika Pada Fasad Van Spaendonck Enterprise House (Sumber: Data Pribadi, 2021).

Berdasarkan gambar 18 bahwa eksterior bangunan Van Spaendonck Enterprise House memiliki desain yang memanfaatkan bukaan sebagai faktor utama dalam aspek estetika bangunan. Material kaca tersebut menjadi ciri khas utama dari bangunan Van 
Spaendonck Enterprise House menciptakan kesan modern minimalis yang terlihat megah dan juga bersifat netral.

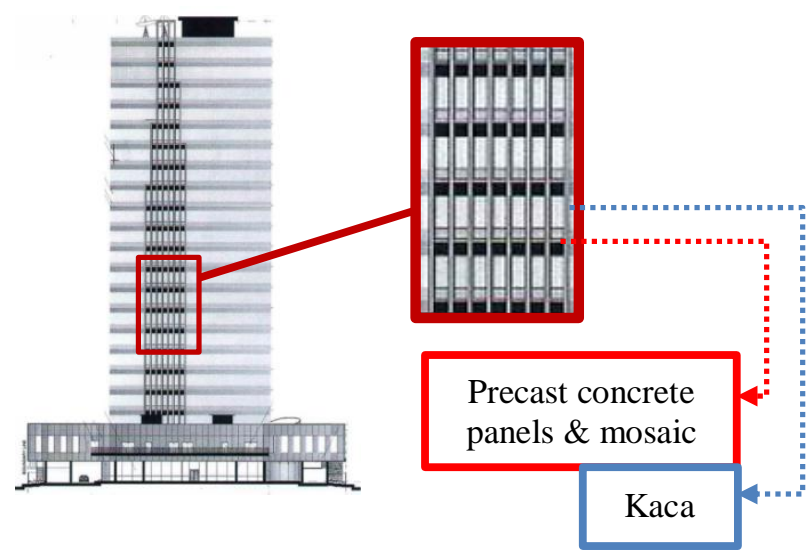

Gambar 19. Pemanfaatan Material Sebagai Estetika Pada Fasad Kantor Permata Kuningan (Sumber: Data Pribadi, 2021).

Berdasarkan gambar 19, pemanfaatan material sebagai estetika dapat dilihat pada ornamen tampak Gedung Kantor Permata Kuningan. Mosaic tile yang berada diatas precast concrete panels memberikan kesan gedung yang sedikit lebih megah dan berkelas. Material kaca juga berkontribusi dalam pemanfaatan material sebagai estetika. Kaca dimanfaatkan di hampir seluruh sisi tampak bangungan, memperkuat kesan bahwa merupakan bangunan office modern minimalis. Tak hanya itu, memanfaatkan kaca juga memberikan kesan netral, mewah dan megah pada bangunan.
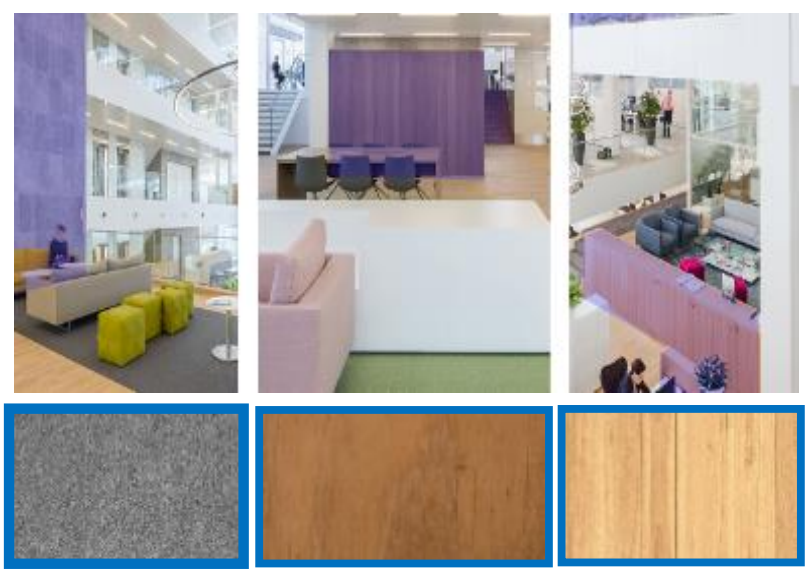

Gambar 20. Pemanfaatan Material Sebagai Estetika Pada Interior Van Spaendonck Enterprise House (Sumber: Data Pribadi, 2021).

Pada interior Van Spaendonck Enterprise House yang dapat dilihat pada gambar 20 terdapat berbagai material yang dimanfaatkan sebagai estetika pada dinding hingga perabot dalam ruangan. Tiap material memberikan kesan yang berbeda-beda, salah satunya adalah pemanfaatan keramik yang memiliki teksture bebatuan. Tekstur bebatuan 
ini memberikan kesan mewah dan warna gelap yang berkesan tenang dapat meningkatkan pengalaman membaca ataupun kegiatan lainnya saat menikmati waktu istirahat. Material kayu juga kerap terlihat pada dinding dan juga permukaan perabot pada interior bangunan. Tekstur kayu menciptakan kesan natural yang juga menekankan sifat berkelanjutan. Pemanfaatan tekstur kayu sebagai estetika merupakan pilihan tepat karena sangat sesuai dengan ciri kah dari modern minimalis.

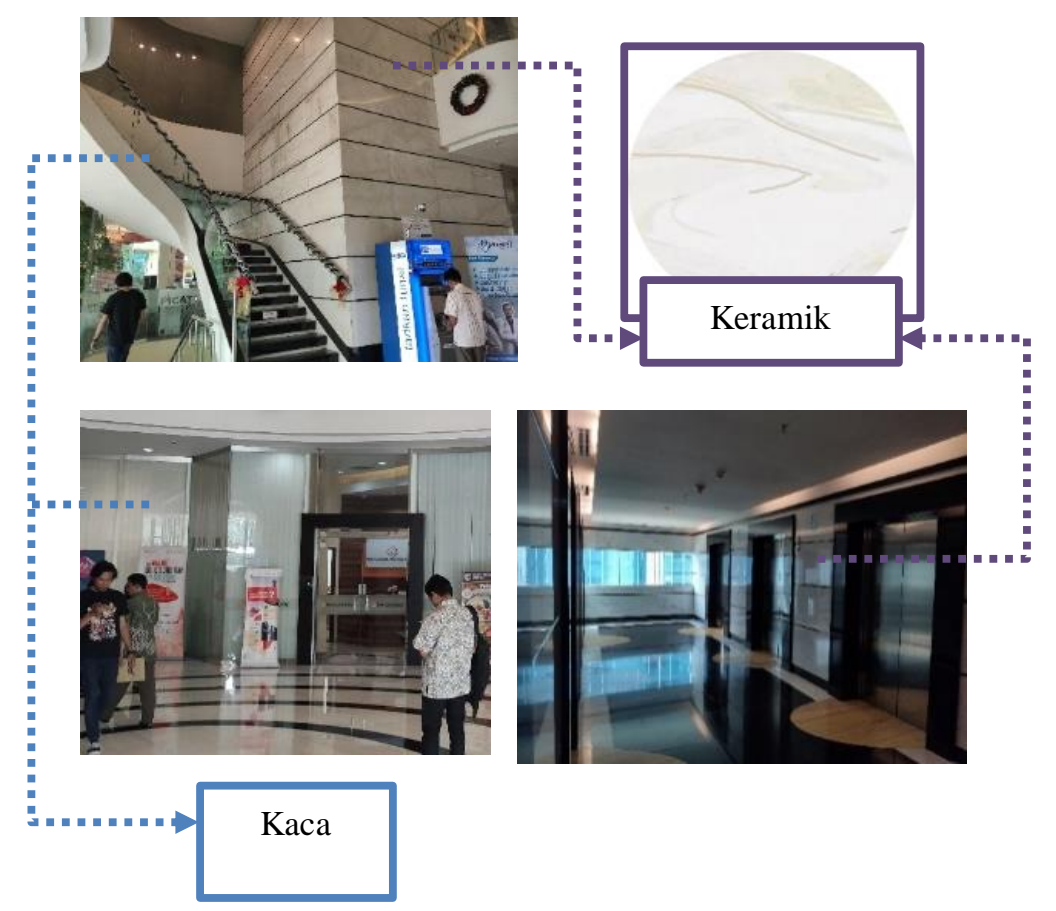

Gambar 21. Pemanfaatan Material Sebagai Estetika Pada Interior Kantor Permata Kuningan (Sumber: Data Pribadi, 2021).

Berdasarkan gambar 21 menjelaskan bahwa penggunaan material sebagai estetika juga dapat ditemukan pada interior bangunan kantor Permata Kuningan. Menggunakan keramik pada dinding lobby, dan selasar lift pada setiap lantai. Pemanfaatan keramik cukup berpengaruh pada desain interior kantor yang menghasilkan kesan desain yang megah, mewah dan berkelas dengan optimal pada interior. Penggunaan kaca sebagai dinding area tenant juga mendukung kesan megah, mewah dan berkelas pada lobby.

Secara keseluruhan dengan menggunakan material sebagai estetika memiliki peran penting dalam pembentukan karakter dari tiap bangunan kantor. Karakteristik mewah, megah dan berkelasdapat menjadi daya tarik dari kantor apabila dilakukan dengan cara pemanfaatan material secara optimal. Penggunaan bukaan secara maksimal merupakan prinsip yang penting dalam arsitektur modern minimalis karena dengan menerapkan prinsip tersebut bangunan Van Spaendonck Enterprise House dan kantor Permata Kuningan akan memiliki banyak keunggulan dibanding bangunan yang tidak menerapkan penggunaan material secara maksimal. 


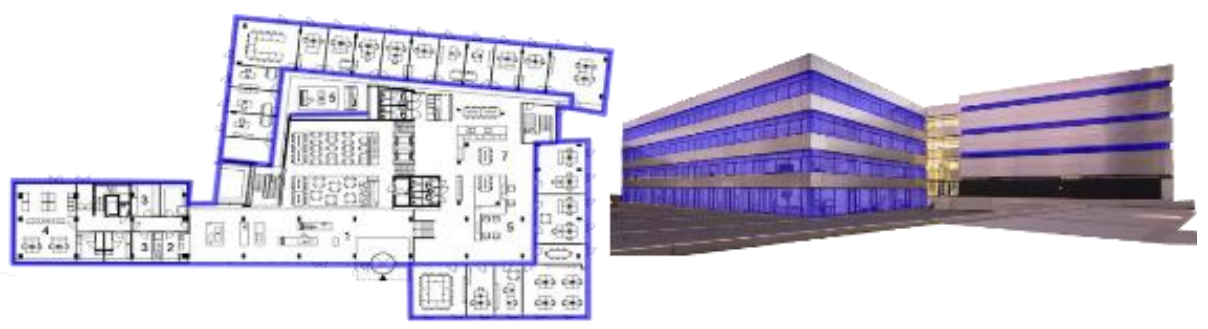

Gambar 22. Letak Bukaan Pada Van Spaendonck Enterprise House (Sumber: Data Pribadi, 2021).

Berdasarkan gambar 22 bahwa letak bukaan pada eksterior maupun interior dapat ditemukan di setiap sisi bangunan. Oleh karena itu pencahayaan dan udara dapat masuk dengan mudahnya dari tiap sisi bangunan. Untuk area publik terdapat light well yang memungkian pencahayaan alami masuk pada ruang yang berada ditengah-tengah bangunan yang dimana pada bangunan lainnya pencahayaan alami sulit untuk masuk sehingga bangunan Van Spaendonck Enterprise House memiliki pencahayaan lebih baik karena sifat berkelanjutan yang diterpakan berdasarkan tema desain bangunan. Pada interior Van Spaendonck Enterprise House, dinding ruangan tiap kantor didominasi oleh penggunaan dinding kaca sehingga pencahayaan dapat dengan leluasa memasuki ruang. Dengan bukaan seperti ini juga meminimalisir penggunaan cahaya buatan.

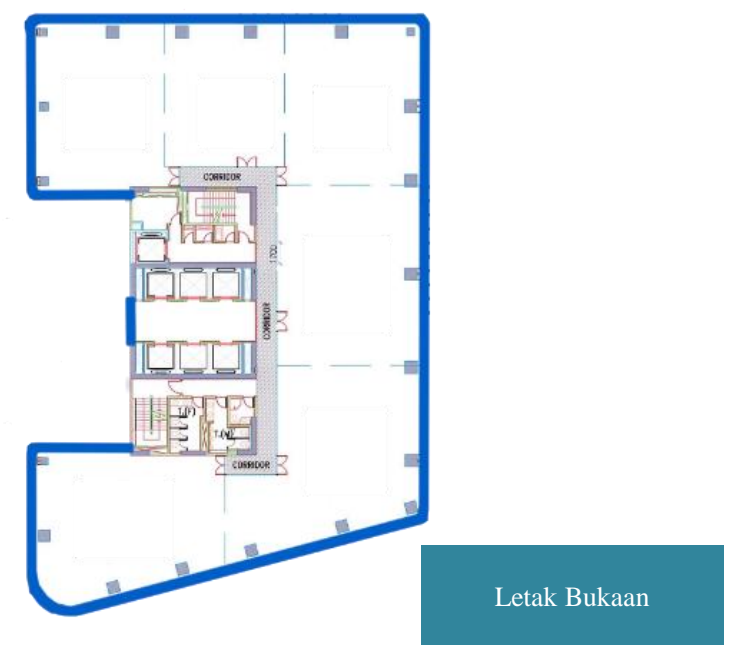

Gambar 23. Letak Bukaan Pada Kantor Permata Kuningan (Sumber: Data Pribadi, 2021).

Berdasarkan layout letak bukaan pada gambar 23, bukaan yang ada pada Gedung Kantor Permata Kuningan terbilang sudah cukup maksimal. Bukaan pada bangunan hampir menyelubungi semua sisi bangunan pada lantai tipikal kantor. Dengan letak bukaan yang terdapat dimana, pendistribusian udara dan cahaya alami pada ruangan didalam kantor akan lebih mudah dan dapat disesuaikan dengan kebutuhan ruang kantor. 
Dengan memaksimalkan bukaan juga dapat meminimalisir biaya bulanan penyewa sehingga lebih menarik minat tenant dikarenakan menghemat biaya.

Prinsip memanfaatkan lingkungan sekitar cukup penting dalam bangunan yang memiliki tema modern minimalis, tak terkecuali Van Spaendonck Enterprise House \& Kantor Permata Kuningan. Memanfaatkan lingkungan memiliki dampak positif bagi bangunan yang menyesuaikannya. Memanfaatkan orientasi bangunan agar ruang yang didalamnya mendapatkan pemandangan yang sesuai dan maksimal dapat memanjakan dan memberi kenyamanan yang lebih bagi pengguna bangunannya. Dengan memanfaatkan lingkungan sekitar berarti memanfaatkan dan menggunakan potensi lahan semaksimal mungkin.

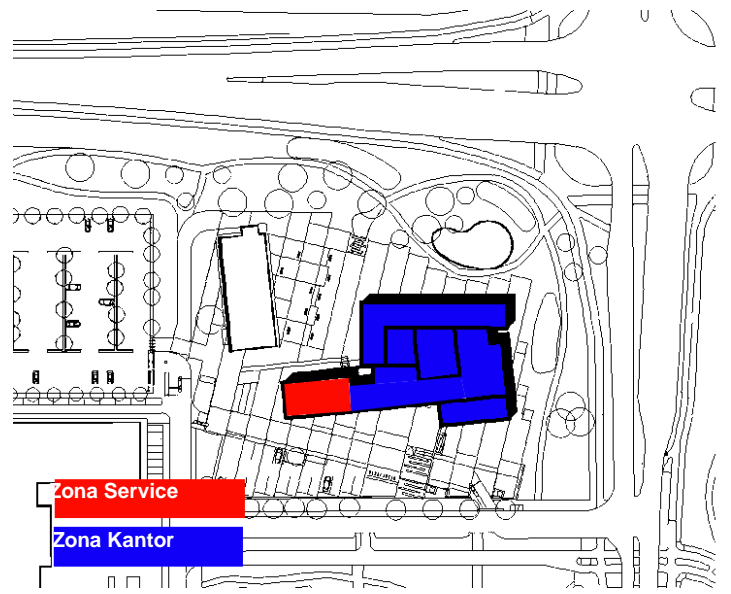

Gambar 24. Blokplan Van Spaendonck Enterprise House (Sumber: Data Pribadi, 2021).

Berdasarkan blokplan yang ditampilkan gambar 24, secara umum Van Spaendonck Enterprise House dibagi dua zona yaitu zona yang digunakan untuk kegiatan perkantoran dan zona untuk menunjang bangunan yaitu zona service. Pada sisi utara, timur dan selatan bangunan terdapat pemandangan yang cukup memanjakan mata dan sisi-sisi ini dimanfaatkan secara optimal oleh zona kantor dimana dapat meningkatkan nilai ruang tersebut. Sementara sisi barat bangunan terdapat bangunan lain dan lapangan parkir yang kurang nyaman bila dimanfaatkan sebagai pemandangan, dan berdasarkan desain bangunan dimanfaatkan oleh zona service sehingga pemandangan tidak terlalu berpengaruh. 


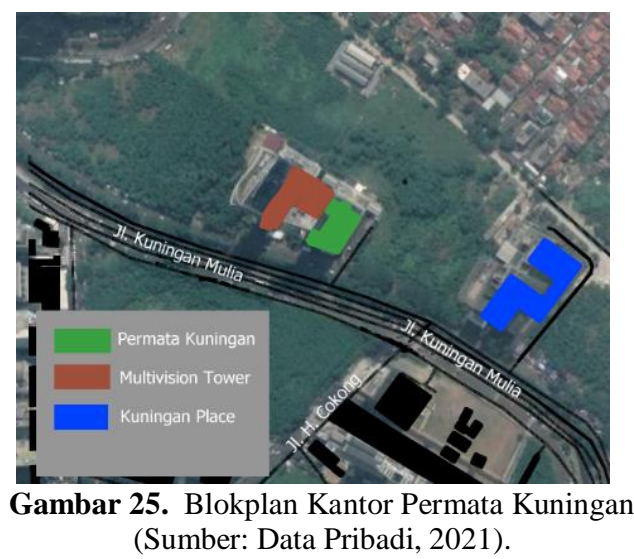

Berdasarkan block plan eksisting Gedung Kantor Permata Kuningan pada gambar 25, site gedung dikelilingi oleh lahan kosong yang akan dibangun bangunan di masa depan. Jika dibandingkan oleh desain tampak, denah dan penempatan ruang, desain dari Gedung Kantor Permata Kuningan sama sekali tidak memanfaatkan lingkungan sekitar seperti pemandangan eksisting, dan kontur. Dari aspek bukaan, disetiap sisi bangunan memiliki desain yang hampir sama jika dibandingkan dengan sisi lainnya.

\section{Kesimpulan}

Berdasarkan hasil penelitian tiga studi kasus yang telah dianalisis dapat ditarik kesimpulan bahwa arsitektur modern minimalis merupakan hasil dari solusi permasalahan keterbatasan dan efisienasi dan juga nilai estetika pada desain bangunan. Untuk menghasilkan desain gedung modern minimalis yang sesuai dan optimal bangunan harus mengikuti prinsip-prinsip dari arsitektur modern yang telah ditentukan. Berikut adalah prinsip-prinsip dan juga contoh penerapannya :

1. Menggunakan Elemen Reduktif Untuk Meningkatkan Efisiensi.

Penerapannya dilakukan dengan berbagai cara seperti mengurangi perabot yang berlebihan untuk meciptakan sirkulasi yang lebih luas yang diwujudkan dengan pengelolaan jumlah peralatan kantor juga mengkosentrasikan penempatan peralatan tersebut. Untuk efisiensi biaya memanfaatkan karakteristik material dan juga meminimalisir penggunaan ornamen sebagai estetika, bertujuan mengurangi biaya pembangunan dan perawatan yang berdampak pada efisiensi jangka panjang.

2. Memanfaatkan elemen horizontal \& vertikal sebagai estetika.

Prinsip ini berhubungan langsung dengan prinsip netralitas. Prinsip ini dapat menggantikan penggunaan ornamen sebagai estetika dengan cara memainkan elemen garis dari suatu bukaan, secondary skin ataupun ornamen yang membentuk susunan harmonis atau bentuk tertentu. Contohnya dengan memainkan susunan bukaan fasad bangunan yang menciptakan pola yang estetis, memanfaatkan ornamen seperti aluminum atau material lainnya untuk menciptakan garis-garis berpola atau bentukan. 
3. Berisfat Netral \& Menghindari Desain Simbolik.

Tujuan dari netralitas dan desain non simbolik agar elemen yang dihasilkan dapat diterima dan dinikmati oleh segala kalangan. Untuk menerapkannya dapat dilakukan dengan menggunakan warna-warna dasar, hitam atau putih pada bangunan. Selanjutnya menggunakan bentuk-bentuk sederhana pada bentuk gubahan, denah maupun ornamen. Elemen bukaan juga dapat digunakan untuk mencapai prinsip ini, dengan bentukan sederhana pada bukaan atau memanfaatkan sifat material. Karakteristik suatu material dapat dimanfaatkan untuk mewujudkan prinsip ini. Contohnya memanfaatkan tekstur kayu, kaca, keramik, beton dan lain-lain pada dinding, perabot, atau permukaan bangunan lainnya.

4. Menggunakan Bentuk-Bentuk Sederhana.

Menggunakan gubahan ataupun layout denah berbentuk sederhana dapat meningkatkan kualitas ruangan. Bentuk sederhana menciptakan elemen desain yang dapat diterima segala kalangan karena tidak bersifat rumit. Prinsip ini dicapai dengan bentukan persegi, atau persegi panjang pada layout denah atau bentuk gubahan dan pemilihan perabot, bentuk bukaan dan ornamen berbentuk persegi, atau persegi panjang.

5. Menggunakan Bahan Sebagai Estetika.

Prinsip ini berkontribusi dalam aspek estetika bangunan. Memanfaatkan material sebagai estetika dapat meningkatkan efektifitas biaya. Material pada elemen estetika dapat meningkatkan netralitas. Prinsip ini dapat dicapai dengan memanfaatkan elemen kaca sebagai dinding. Contoh lainnya dalah memanfaatkan tekstur kayu, keramik, beton dan material lainnya pada dinding dan perabot.

6. Memaksimalkan Penggunaan Bukaan.

Prinsip ini berhubungan langsung dengan kualitas kenyamanan pada bangunan dikarenakan mempengaruhi penghawaan dan pencahayaan. Untuk penerapannya dengan cara menempatkan bukaan disetiap sisi bangunan yang terdapat aktifitas didalamnya. Penggunaan dinding partisi, lightwell atau bukaan khusus lainnya juga mempengaruhi prinsip ini.

7. Memanfaatkan Lingkungan Sekitar.

Prinsip ini berfungsi untuk memaksimalkan potensi bangunan. Dengan memanfaatkan lingkungan sekitar, pencahayaan dan penghawaan dapat dimanipulasi sesuai keinginan. Prinsip ini dapat meningkatkan kualitas ruangan yang digunakan dengan cara penyusuan ruangan yang menyesuaikan dengan keadaan lingkungan sekitar misal, area atau zona service dapat menghadap gedung atau lahan parkir yang tidak memiliki nilai estetika. Dan untuk ruang yang sering digunakan oleh dihadapkan dengan pemandangan yang indah atau sesuai dengan aktifitas. 


\section{Bibliography}

Abdullah, M. (2014). Manajemen dan evaluasi kinerja karyawan. Aswaja Pressindo.

Lukito, Y. N., \& Handoko, B. P. (2018). The Crux of Minimalist Architecture: A Local Strategy of Housing Design in Jakarta or a Break Free from Traditions? IOP Conference Series: Materials Science and Engineering, 316(1), 12006.

Nuraida, I. (2018). Manajemen administrasi perkantoran. Kanisius.

Prasanti, D. (2018). Penggunaan Media Komunikasi Bagi Remaja Perempuan.

Rozarie, C. V. R. A. De, \& Indonesia, J. T. K. R. (2017). Manajemen sumber daya manusia.

Sedarmayanti. (2017). Perencanaan dan Pengembangan Sumber Daya Manusia. Refika Aditama.

Sulastri, L. (2016). Studi Kelayakan Bisnis untuk Wirausaha. LGM-LaGood's Publishing.

Wahjutami, E. L. (2017). Kesenjangan Konsep Dan Penerapan Gaya Modern Minimalis Pada Bangunan Rumah Tinggal. Mintakat: Jurnal Arsitektur, 18(1).

Walidonna, A. R. (2017). Desain Interior Coworking Space DiLo Surabaya untuk Meningkatkan Produktifitas dan Inovasi Pengguna. Institut Teknologi Sepuluh Nopember.

Wicaksono, A. A., \& Tisnawati, E. (2014). Teori interior. Griya Kreasi. 